\title{
Mineral Composition of Sapropelles of Lakes of the Right Bank of the Ob River (Middle Ob Region)
}

\author{
M. P. Sartakov ${ }^{1}$, E. M. Osnitsky ${ }^{1}$, K. Iu. Kudrin ${ }^{1} \&$ N. S. Larina ${ }^{2}$ \\ ${ }^{1}$ Yugra State University, Khanty-Mansiysk, Russia \\ ${ }^{2}$ Tyumen State University, Tyumen, Russia \\ Correspondence: M. P. Sartakov, Yugra State University, Khanty-Mansiysk, Russia. E-mail: mpsmps@bk.ru
}

Received: September 6, 2019

Accepted: September 26, 2019

Online Published: October 18, 2019

doi:10.5539/jmbr.v9n1p77

URL: https://doi.org/10.5539/jmbr.v9n1p77

\begin{abstract}
The objective of this work is to study the mineral composition of bottom sediments of eight small lakes located on the right bank of the Ob River (Western Siberia) in the Surgut region of the Khanty-Mansiysk Autonomous Okrug - Yugra. The studies were carried out using wave dispersive X-ray fluorescence (WDFR) spectroscopy. The content of organic substances, ash, and oxides in the ash in the samples was determined. Based on these data, the studied bottom sediments were classified. The bottom sediments of Lake S-1 are siltstone sands, lakes Vach Lor and S189 - weakly sapropelic siltstone sands, lakes S-5, S-6, S-3, S-89, and S-294 - typical sapropels. The article presents the content of the main elements in the ash of the studied samples.
\end{abstract}

Keywords: Sapropel, Trace Elements, Organic Matter, Wave Dispersive X-Ray Fluorescence Spectroscopy

\section{Introduction}

Sapropels are modern or subfossil, fine-structured, colloidal deposits of continental reservoirs. Their composition includes the remains of microscopic aquatic organisms, a significant amount of organic matter, a certain amount of inorganic components of biogenic origin, as well as mineral impurities of a salutary nature. Peat is genetically close to sapropels. A finer structure is the main difference between sapropels and peat. In addition, the primary sources of organic matter are different. Peat is biogenic humic formations, the primary sources of organic matter of which are carbohydrates of peat-forming plants. In sapropels, the primary sources of organic matter are fats and protein substances of sapropel-forming organisms - plankton and algae, which causes a difference in the chemical composition of peat and sapropel. According to the content of the organic and inorganic components, sapropels belong to the organic-mineral and organic groups of bottom sediments. Sapropels are contrasted with high-ash lake deposits - clays, sands, marls, taking $15 \%$ of the content of organic matter as a conditional border for this distinction (Aksoy, 2016; Korde, 1960).

Sapropelic deposits attract the attention of researchers in connection with the possibilities of their use for practical purposes. Sapropel is used in medicine as applications, diluted baths for mud therapy, in agriculture as fertilizer, in animal husbandry as a mineral supplement (Shtin, 2005; Becerril-Ángel et al, 2017). The theoretical interest in sapropels lies in the opinion of a number of scientists that a long time ago they were the material carbon sedimentary rocks were formed of (Zanin, Zamirailova, Livshits, \& Eder, 2008).

The objective of this work was to study the mineral composition of sapropels of eight lakes from the right bank of the $\mathrm{Ob}$ river (Western Siberia).

\section{Research Objects and Methods}

Sapropel was sampled from eight small lakes located on the right bank of the Ob River in the Surgut region of the Khanty-Mansiysk Autonomous Okrug - Yugra. Geomorphologically, the lakes are located on the second floodplain terrace. The water surface area of the lakes ranges from 2.2 to 154.7 ha, the water depth ranges from the first tens of centimeters to 4.8 meters. Samples for laboratory and analytical tests were taken in all the lakes studied.

Figure 1 shows maps of the location of the lakes and the sampling points of sapropels for the study. 


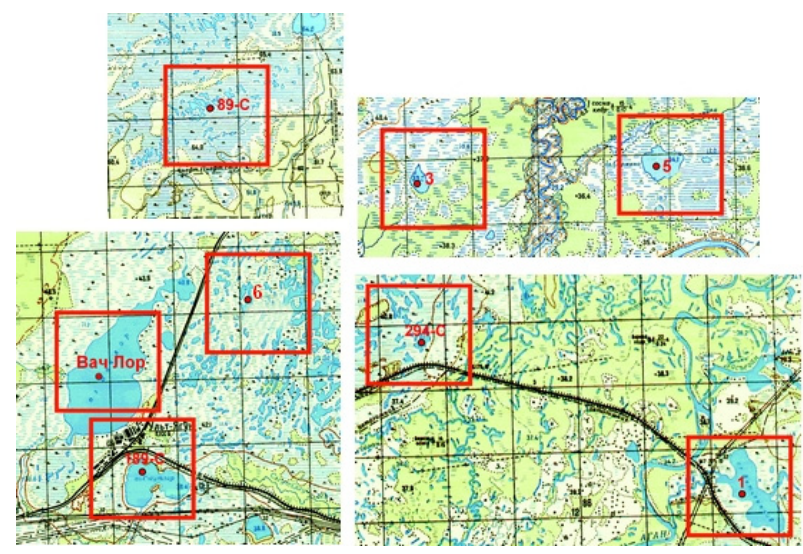

Figure 1. Maps of the location of lakes and drilling points

Most lakes are supplied by spring floods and precipitation. The lakes are located among cedar, pine, birch forests, and vast swamps. Mixed overgrowing type of reservoirs is a combination of rafts and vast thickets. The bottom of the lake is covered with a carpet of macrophytes.

A sampling of sapropels and lake waters was performed according to the "Guidelines for hydrobiological analysis of surface waters and bottom sediments" (Gidrometeoizdat, 1983). A sampling of lake water for general chemical analysis was carried out from a depth of $1 \mathrm{~m}$ into a $1 \mathrm{~L}$ plastic container. The determination of macro- and microelements was carried out in samples of dry sapropel using wave dispersive X-ray fluorescence (WDFR) spectroscopy in the engineering center of composite materials based on compounds of tungsten and rare-earth elements of the State Agrarian University of Northern Trans-Urals. Samples were analyzed on an ARL Optim'X spectrometer equipped with the OXSAS IT complex for instrument control and processing of results (Shackley, 2011). Sample preparation and analysis were carried out according to GOST 33850-2016 "Soils. Determination of chemical composition by X-ray fluorescence spectrometry". The concentration was calculated using the method of fundamental parameters with correction coefficients of the interelement influence of the UniQuant module (van Hans, 2000).

\section{Results and Discussion}

The results of the study of the trace element composition of lake waters are presented in Table 1.

Table 1. Trace element composition of the waters of the investigated lakes

\begin{tabular}{llllllll}
\hline Lake code & $\mathrm{Cd}, \mathrm{mg} / \mathrm{dm}^{3}$ & $\mathrm{Ni}, \mathrm{mg} / \mathrm{dm}^{3}$ & $\mathrm{Cr}, \mathrm{mg} / \mathrm{dm}^{3}$ & $\mathrm{Fe}, \mathrm{mg} / \mathrm{dm}^{3}$ & $\mathrm{Mn}, \mathrm{mg} / \mathrm{dm}^{3}$ & $\mathrm{Zn}, \mathrm{mg} / \mathrm{dm}^{3}$ & $\mathrm{~Pb}, \mathrm{mg} / \mathrm{dm}^{3}$ \\
\hline S-1 & $<0.0002$ & $<0.005$ & 0.0056 & 0.213 & 0.104 & $<0.005$ & 0.0025 \\
S-89 & $<0.0002$ & $<0.005$ & $<0.0025$ & 1.420 & 0.104 & 0.008 & 0.0026 \\
S-3 & $<0.0002$ & $<0.005$ & $<0.0025$ & 0.068 & 0.036 & $<0.005$ & $<0.0020$ \\
S-6 & $<0.0002$ & $<0.005$ & $<0.0025$ & 0.144 & 0.026 & 0.076 & $<0.0020$ \\
S-5 & $<0.0002$ & $<0.005$ & $<0.0025$ & 0.128 & 0.028 & 0.009 & 0.0054 \\
Vach Lor & $<0.0002$ & $<0.005$ & 0.003 & 1.354 & 0.322 & 0.008 & 0.0039 \\
S-189 & $<0.0002$ & $<0.005$ & 0.0035 & 4.420 & 0.706 & 0.007 & 0.0012 \\
S-294 & $<0.0002$ & $<0.005$ & $<0.0025$ & 2.041 & 0.216 & 0.021 & 0.0022 \\
\hline
\end{tabular}

The content of metal ions of $\mathrm{Cd}, \mathrm{Ni}, \mathrm{Cr}, \mathrm{Zn}, \mathrm{Pb}$, indicating anthropogenic pollution of lakes, is minimal. The study revealed that the lake is not subject to severe anthropogenic pollution. Fe and Mn enter the lakes from groundwater rich in these ions. The content of $\mathrm{Fe}$ ions lies in the range from 0.068 to $4.42 \mathrm{mg} / \mathrm{dm}^{3}, \mathrm{Mn}$ from 0.026 to $0.706 \mathrm{mg} / \mathrm{dm}^{3}$.

The Fe content in lake waters correlates well with the Mn content (Fig. 2). The highest content of Fe and Mn is observed in the waters of Lake S-189, the smallest in the waters of Lakes S-1, S-3, S-6, and S-5. 


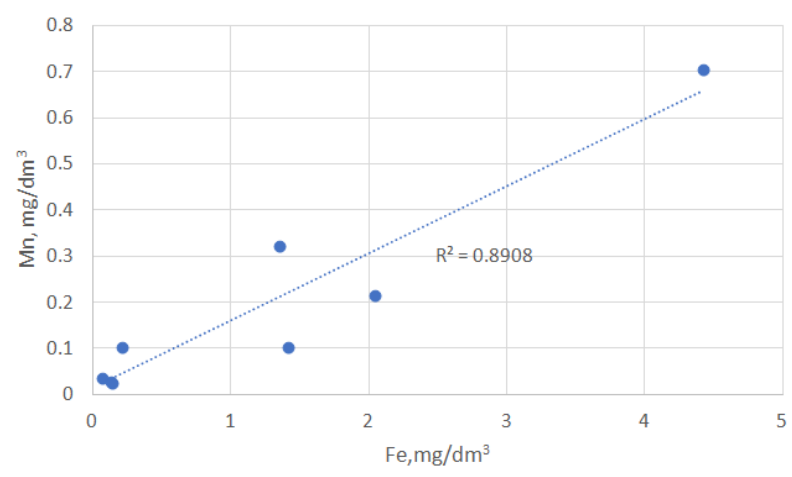

Figure 2. Fe-to-Mn relationship in lake waters

Table 2 presents data on permanganate oxidizability, chloride and sulfate ion content, hardness, and petroleum product content.

Table 2. The results of the study of lake waters (units of measurement)

\begin{tabular}{llllll}
\hline Lake code & $\begin{array}{l}\text { Permanganate } \\
\text { oxidation, } \mathrm{mg} / \mathrm{dm}^{3}\end{array}$ & $\begin{array}{l}\text { Chloride ion, } \\
\mathrm{mg} / \mathrm{dm}^{3}\end{array}$ & $\begin{array}{l}\text { Sulfate ion, } \\
\mathrm{mg} / \mathrm{dm}^{3}\end{array}$ & $\begin{array}{l}\text { Hardness, degrees of } \\
\text { hardness }\end{array}$ & $\begin{array}{l}\text { Petroleum products, } \\
\mathrm{mg} / \mathrm{dm}^{3}\end{array}$ \\
\hline S-1 & 23 & 14 & 12 & $<0.1$ & $<0.02$ \\
S-89 & 32 & 3 & 41 & $<0.1$ & $<0.02$ \\
S-3 & 8.4 & 2.2 & 21 & $<0.1$ & $<0.02$ \\
S-6 & 23 & 27 & 28 & $<0.1$ & $<0.02$ \\
S-5 & 22 & 2.2 & 7 & $<0.1$ & $<0.02$ \\
Vach Lor & 30 & 11 & 15 & $<0.1$ & $<0.02$ \\
S-1 99 & 9 & 2.6 & 18 & $<0.1$ & $<0.02$ \\
S-294 & 48 & 15 & 22 & $<0.1$ & $<0.02$ \\
\hline
\end{tabular}

All investigated water is not contaminated with petroleum products and is not hard. Permanganate oxidation is a value characterizing the content of organic and mineral substances in water oxidized by potassium permanganate. This indicator reflects the total concentration of organics in the water. The smallest content of the total concentration of organics is observed in lakes S-3 and S-189, the highest - in S-294.

Figure 3 shows a chart of the content of organic matter (OM) in the studied sapropels and silicon oxide in the ash.

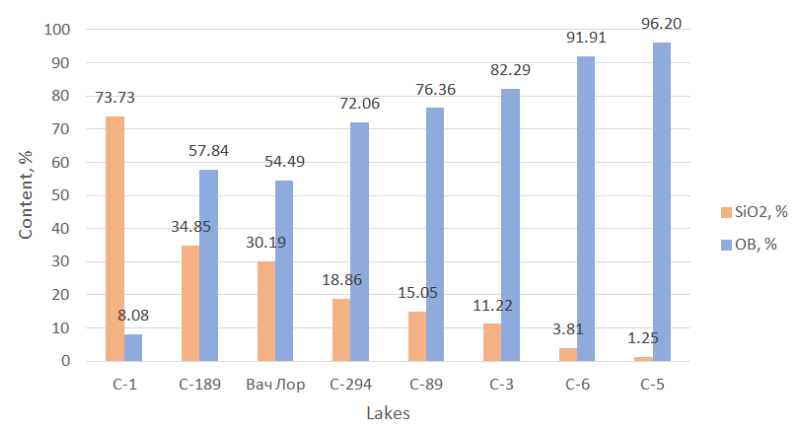

Figure 3. OM content in sapropels and $\mathrm{SiO}_{2}$ in ash

Bottom sediments can be divided into groups according to their OM composition. The content of organic matter is less than $10 \%$ - siltstone sands and clay silt, organic matter 10-30\% - weakly sapropel siltstone and clay silt, organic matter 30-50\% - clay sapropelic silt, organic matter 50-70\% - sapropelic clay silt, organic matter more than $70 \%$ - sapropels (Shtin, 2005). Based on this classification, lake sediments of Lake S-1 are siltstone sands, lakes S-189, Vach Lor - sapropelic-clay silt, lakes S-294, S-89, S-3, S-6, S-5 - sapropels.

According to another classification, sapropels can be divided into type, class, and kind according to the content of 
ash, calcium, and iron oxides, and biological and mineralogical composition (Shtin, 2005). Table 3 presents this classification.

Table 3. Classification of the studied sapropels

\begin{tabular}{|c|c|c|c|c|c|c|c|}
\hline \multirow{2}{*}{ Lakes } & \multicolumn{3}{|c|}{ Content, $\%$} & \multirow{2}{*}{ Chemical and mineralogical composition } & \multirow{2}{*}{ Type } & \multirow{2}{*}{ Class } & \multirow{2}{*}{ Kind } \\
\hline & Ash & $\mathrm{CaO}$ & $\mathrm{Fe}_{2} \mathrm{O}_{3}$ & & & & \\
\hline S-5 & 3.80 & 0.434 & 0.383 & \multirow{5}{*}{ Organic residues $>45 \%$} & \multirow{5}{*}{ Biogenic } & \multirow{5}{*}{ Organic } & \multirow{5}{*}{-} \\
\hline S-6 & 8.09 & 0.625 & 0.536 & & & & \\
\hline $\mathrm{S}-3$ & 17.71 & 1.190 & 0.746 & & & & \\
\hline S-89 & 23.64 & 2.550 & 0.898 & & & & \\
\hline S-294 & 27.94 & 1.120 & 0.876 & & & & \\
\hline Vach Lor & 45.51 & 1.480 & 2.160 & Organic residues - $45 \%$ & \multirow{3}{*}{ Clastogenic } & \multirow{2}{*}{ Organic-silicate } & \multirow{2}{*}{ Organic-sandy } \\
\hline S-189 & 42.16 & 0.995 & 2.450 & $\mathrm{SiO}_{2}>30 \%$ & & & \\
\hline S-1 & 91.92 & 1.100 & 1.200 & $\begin{array}{l}\text { Organic residues }<45 \% \\
\mathrm{SiO}_{2}>30 \%\end{array}$ & & Silicate & Sandy \\
\hline
\end{tabular}

According to this classification, the same groups are distinguished. Sapropels of lakes S-5, S-6, S-3, S-89, S-294 have a biogenic type and organic class. They can be used as fertilizers, feed supplements, therapeutic mud, for the production of building materials, adhesives, and drilling fluids. The sapropels of the lakes Vach Lor, S-189, S-1 are clastogenic but differ in class and type. They can be used as fertilizers, therapeutic mud. The ash content in sapropel increases together with the iron oxide content in the ash, with the exception of sample S-1, which is siltstone sand (Fig. 4).

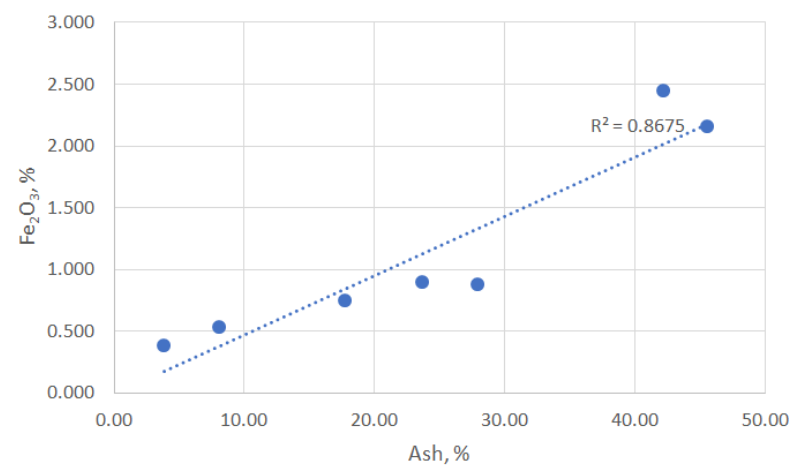

Figure 4. $\mathrm{Fe}_{2} \mathrm{O}_{3}$ content in ash to ash content in sapropels relation curve

Table 4 presents the main elements included in the ash of the studied sapropels.

Table 4. Elemental composition of sapropel ash

\begin{tabular}{|c|c|c|c|c|c|c|c|c|}
\hline \multirow{2}{*}{ Elements } & \multicolumn{8}{|c|}{ Lakes } \\
\hline & S-1 & S-189 & Vang-Lor & S-294 & S-89 & S-3 & S-6 & S-5 \\
\hline $\mathrm{Si}, \%$ & 34.470 & 16.290 & 14.110 & 8.820 & 7.040 & 5.240 & 1.780 & 0.583 \\
\hline $\mathrm{Al}, \%$ & 5.390 & 1.050 & 3.780 & 1.840 & 1.120 & 0.955 & 0.565 & 0.361 \\
\hline $\mathrm{Fe}, \%$ & 0.840 & 1.710 & 1.510 & 0.613 & 0.628 & 0.522 & 0.375 & 0.268 \\
\hline $\mathrm{K}, \%$ & 1.980 & 0.192 & 0.994 & 0.590 & 0.259 & 0.204 & 0.154 & 0.038 \\
\hline $\mathrm{Na}, \%$ & 0.825 & 0.063 & 0.287 & 0.116 & 0.057 & 0.067 & 0.096 & 0.016 \\
\hline $\mathrm{Ca}, \%$ & 0.787 & 0.712 & 1.060 & 0.804 & 1.820 & 0.850 & 0.447 & 0.310 \\
\hline $\mathrm{Mg}, \%$ & 0.348 & 0.164 & 0.390 & 0.141 & 0.132 & 0.126 & 0.066 & 0.054 \\
\hline
\end{tabular}

Among the presented elements, two groups can be distinguished. The first group of elements ( $\mathrm{Al}, \mathrm{K}, \mathrm{Na})$ makes up the terrigenous (clastic) part of the bottom sediment. The second group of elements $(\mathrm{Ca}, \mathrm{Mg})$ makes up the carbonates. $\mathrm{Sr}$, also included in this group, was not identified. The third group of elements ( $\mathrm{Zn}, \mathrm{Cu}, \mathrm{Hg}$ ) associated 
with anthropogenic effects was not identified.

\section{Conclusion}

The bottom sediments of Lake S-1 are siltstone sands, clastogenic, of silicate class and sandy type. They are characterized by a higher ash content $(91.92 \%)$ and a higher content of elements constituting the terrigenous part $(\mathrm{Al}, \mathrm{K}, \mathrm{Na})$ relative to other samples studied. The Fe content is moderate and does not fit into the overall dependence of the iron content in the ash on the ash content in the sample. No traces of anthropogenic effects have been identified. The main scope of application: fertilizers and therapeutic mud.

The bottom sediments of Vach Lor, S-189 lakes are sapropelic-clay silts, clastogenic, of organic-silicate class and organic-sandy type. They are characterized by an average ash content $(45.51 \%, 42.16 \%$, respectively) and an average content of elements constituting the terrigenous part ( $\mathrm{Al}, \mathrm{K}, \mathrm{Na}$ ) relative to other samples studied. The Fe content is the highest. No traces of anthropogenic effects have been identified. The main scope of application: fertilizers and therapeutic mud.

Bottom sediments of lakes S-5, S-6, S-3, S-89, S-294 are typical sapropels, of biogenic type and organic class. The ash content is the smallest and found in S-5, S-6, S-3, S-89, S-294. The content of elements constituting the terrigenous part ( $\mathrm{Al}, \mathrm{K}, \mathrm{Na}$ ) and $\mathrm{Fe}$ is the smallest and found in S-5, S-6, S-3, S-89. No traces of anthropogenic effects have been identified. The main scope of application: fertilizers, feed supplements, therapeutic mud, for the production of building materials, adhesives, and drilling fluids.

\section{Acknowledgments}

This study was performed with the financial support of the Russian Foundation for Basic Research (Agreement No. 18-44-860010) and the Government of the Khanty-Mansiysk Autonomous Okrug - Yugra (Agreement No. 06/19.0147/5.5/19-YSU-128).

\section{Conflict of interests}

The authors declare that there is no conflict of interests regarding the publication of this paper.

\section{References}

Aksoy, H. (2016). Nocturnal enuresis frequency in children and anxiety-depression risks of parents. Journal of Clinical and Experimental Investigations, 7(2), 150-156.

Gidrometeoizdat, L. (1983). Guidelines for hydrobiological analysis of surface water and bottom sediments (p. 239).

Korde, N. V. (1960). Biostratification and typology of Russian sapropels (p. 219). - M.: Publishing House of the Academy of Sciences of the USSR.

Becerril-Ángel, M., Castillo-Pérez, J. J., Montiel-Jarquín, Á. J., Villatoro-Martínez, A., \& García-Cano, E. (2017). Aspects of the submission of articles to scientific journals. European Journal of General Medicine, 14(2), $47-50$.

Shackley, M. S. (Ed.) (2011). X-Ray Fluorescence Spectrometry (XRF) in Geoarchaeology. Retrieved from http://www.newbooks-services.de/MediaFiles/Texts/1/9781461436201_Excerpt_001.pdf

Shtin, S. M. (2005). Lake sapropels and their integrated development (p. 373). - M.: Publishing House of Moscow State University.

van Hans, A. (2000). Sprang Fundamental parameter methods in XRF spectroscopy. Advances in X-ray Analysis, 42.

Zanin, Yu. N., Zamirailova, A. G., Livshits, V. R., \& Eder, V. G. (2008). On the role of skeletal and non-skeletal biogenic material in the formation of organic matter of the Bazhenov formation. Geology and Geophysics, 49(4), 357-366.

\section{Copyrights}

Copyright for this article is retained by the author(s), with first publication rights granted to the journal.

This is an open-access article distributed under the terms and conditions of the Creative Commons Attribution license (http://creativecommons.org/licenses/by/4.0/). 